\title{
Mediating Islam and Modernity: Sir Syed, Iqbal and Azad
}

\author{
Tauseef Ahmad Parray \\ New Delhi, India: Viva Books Private Limited, 2019. 182 pages.
}

The question of Islam's compatibility with modernity (and other interrelated aspects like democracy, rationality, nationalism, etc.) has been debated for more than two centuries. In the Subcontinent, this debate started with British imperialism (the so-called British Raj, 1857-1947). Scholars like Chirag Ali (d. 1895), Sir Syed Ahmad Khan (d. 1898), Allama Iqbal (d. 1938), Abul Kalam Azad (d. 1958), Shibli Numani (d. 1914), Mumtaz Ali (d. 1974), Syed Mawdudi (d. 1979), Amin Ihsan Islahi (d. 1997), and Abul Hassan Ali Nadwi (d. 1999) offered various critical responses. The debate still manifests in different forms, whether regarding nationalism or secularism, rationality or progressive politics. A plethora of mostly apologetic literature has been produced on the question. A recent addition to this literature is Parray's Mediating Islam and Modernity.

The main objective of the book is to analyse the thought and the vision of three South Asian "pioneering modernists" on some crucial issues, including Muslim responses to imperialism, $i j m \bar{a}^{\prime}$ and $i j t i h \bar{a} d$, democracy, and other interrelated themes. The book combines the scholarship of past and present, examines these South Asian reformers in the broader context, 
and highlights their relevance in contemporary era. The book is theoretical in nature and adopts descriptive, critical, and comparative methodologies. It comprises four chapters, excluding the preface and epilogue, with a foreword by Irfan Ahmad (a renowned anthropologist presently at Max Planck Institute, Göttingen) titled "On Writing History" in which he raises fundamental historiographical questions and pushes the historian to go beyond established binaries (barbarian/civilized, traditional/modern, terrorist/ democrat, etc.).

Chapter One ("British Colonialism and 'Pioneering Modernists' of Colonial India on Reconciling 'Islam and Modernity"') provides a sketch of modernist/reformist thought in South Asia, with an overview of British colonialism and Muslim responses, and a focus on contextualizing terms like 'modernity' and 'traditions'. The author defines modernism as "a movement to reconcile Islamic faith with modern values." He argues that Islamic modernism emerged in the mid-nineteenth century as a response to European colonialism, "which pitched the Muslim world into crisis" (2). In India the three broad responses to British imperialism came from "traditionalists," "reformists/proto-fundamentalists," and "modernists." The last of these sought to generate a new synthesis of Islam within the frames of tajdid (revival) and ișlāh (reform).

The second chapter ("Muslim Responses to Imperialism: Contribution of Sir Sayyid Ahmad Khan as a Muslim Modernist-cum-Educational Reformer") details Sir Sayyid's socio-educational programs. He believed that "Islam is in full correspondence with reason" (34) and sought a new theology of Islam by accepting Western thought. In order to put his educational programmes into practice, he established Aligarh Scientific Society (1864); translated forty European books dealing with different themes; established the Modern School at Ghazipur (1886) to promote and establish educational committees in northern India; established Muhammadan Anglo-Oriental Collage at Aligarh (1874) along the Oxbridge model, which in 1920 became Aligarh Muslim University (AMU); and established the Muhammadan Anglo-Oriental Educational Conference (1886) for the promotion of western education in Muslim India. The author argues that Sir Sayyid is a source of inspiration for reformists and modernists across the globe.

The third chapter ("Islamic Modernist and Reformist Thought in Colonial India: A Comparative Study of Sir Sayyid and Muhammad Iqbal”) situates Sir Sayyid and Iqbal's modernist visions in broader South Asia, especially on the topics of natural science, legal reasoning, and political 
organization. Sir Sayyid, like Jamal al-Din Afghani and Muhammad 'Abduh in the Middle East, stressed the need for a modern 'ilm kalām (scholastic theology), and Iqbal called for the "reconstruction" of religious thought and declared taqli $d$ to be a form of a dogmatic slumber. In terms of religious law, Sir Sayyid's ultimate emphasis was on ijtihād as the inalienable right of every individual Muslim, and thus he rejected the classical principle of ijmá as confined to the 'ulama' (50). He believed that Islam is the only religion that can accommodate the changing times and context and that he continued the legacy of Shah Waliullah in ijtihād. His resolute rationality advocated a slogan: "Islam is nature and nature is Islam" (47); likewise, he held that "the Qur'an as the word of God cannot be in conflict and contradiction with the nature as the work of God," so in cases "when a contradiction emerged between scientific fact and religious rule (text), then the latter must be reinterpreted according to scientific evidences" (54). The author also highlights the criticism of Sir Sayyid's religious thought by scholars like Fazlur Rahman (d. 1988), who believed that he "was not a keen religious thinker, nor primarily and deeply religious, but was led by the inner logic of Muslim intellectual history to justify his cultural progress attitude theologically" (56). Maulana Ashraf Ali Thanawi (d. 1943) declared Sir Sayyid a heretic (mubtadi) and branded his associates a new naturalist sect (firqa muhditha nechariyya); Afghani wrote a fatwa against him and his followers as materialists.

The next portion of the chapter focuses on Iqbal's views on ijma $\bar{a}^{c}$ and ijtihād and the Islam-democracy debate. The author contends that unlike Sir Sayyid, Iqbal was more critical of Western thought. He believed that the major reason for Muslim decline was an "inability or unwillingness to subject the legal system to intellectual scrutiny, particularly with reference to ijtihad." He sought the re-codification of fiqh and to transfer the right to interpret Islam from the religious clergy to national assembly. The author contends that Iqbal indeed criticized democracy, but never rejected the whole idea. In fact, he was against the imperfections of modern/Western democracy, but believed that democracy itself was the best form of government for Muslim community. Especially, that is, since Islam is an egalitarian faith with no room for an elect clergy.

The fourth chapter (“Islamic Democracy' or 'Democratic Islam': Re-Reading Abul Kalam Azad on Shura-Democracy Nexus") explores how Azad believed that a shura-cracy (also 'Islamic democracy', islami jumhuriyya) is an alternative to western democracy. The author compares these 
themes in Azad's exegetic work (Tarjumān al-qur'ān) with some prominent twentieth-century Urdu exegeses. In the final section of the chapter, the author highlights the contemporary relevance of Azad's Islamic-democracy theory by bringing together the views of various political experts.

The book not only analyses Sir Sayyid, Azad, and Iqbal on Islam and modernity but also reveals their continued relevance in present times through interpreting a wide variety of Urdu and English sources. In sum, Parray's Mediating Islam and Modernity highlights crucial contemporary issues and will be helpful for students and specialists in the fields of Islamic Studies, South Asian history, anthropology, and related subjects.

Owais Manzoor Dar Doctoral Candidate, Department of Islamic Studies Jamia Millia Islamia, New Delhi, India 